\title{
Okonko Cultural Practice, Its Support of Security of Human Lives and Property in Ikwuano
}

\author{
Ubani Nbili Chiniaobi
}

Methodist Theological Institute, Mission Hill Umuahia, USA

Copyright $\bigcirc 2019$ by authors, all rights reserved. Authors agree that this article remains permanently open access under the terms of the Creative Commons Attribution License 4.0 International License

\begin{abstract}
The paper is meant to bring to our knowledge some of the good cultural practices that helped to build Igbo as a people. As a borrowed culture of the now Akwa Ibom people, Okonko became a colonial cult which the Igbo man will call "Mbiara Chiwa". It grew and became the governing body in all the villages in Ikwuano and other villages and towns in Igbo land. Where it was found, its influence stretched to all aspects of lives of the Igbo man including religion, social and political lives. This was achieved through wielding all the titled, wealthy and elderly men of the land who asserted their influence on the community though Okonko. Okonko became the task master over every individual both on justice, security, moral, social and religious aspects of life. Due to the optimistic determination of Okonko to assert influence over every individual in the community, the elite in the society had no choice than to belong and by so doing; all the powers for making decision were given to her. It was discovered that there were many good and bad things found in Okonko and like every other human society, when corrupt men joined the society and began to introduce strange laws, the society become corrupted. At this point, the Church came and condemned everything about this cult that had brought life and light to many people before now. The intention of this paper is to say no, that everything in this cult is not just bad. Therefore, some of its practices could be preserved to help inculcate the usefulness of culture in the lives of the coming generations. Okonko should purge herself of evil men, change her religious focus and still maintain her socio-cultural aspects as to remain a memorial for our future generations.
\end{abstract}

Keyword Okonko Cultural Practice, Ikwuano Cult, Human Life, Cultural Practice, Community

\section{Introduction}

Prior to the advent of Christianity in the $13^{\text {th }}$ Century, the
Ikwuano People like all other Igbo and Africans, had their ethos and world-view fully developed? Their culture which included: their knowledge of the world around them, their style of governance, moral, education, religious rites, laws, customized way of doing things, and habits. Everybody knew where he was going; the picture of how things were done was already ingrained in their memory. The people's concept of nature, self, society, religion, ritual, belief, comfort, were already formed and known by all. To this end, Agha notes that people's traditional religious beliefs and ritual practices were based on the idea which explained why things were going the way they were. He said that they believed in the supreme creator of the universe whom they call Chineke (God who creates), Chukwu (Chi-ukwu) (The high God) Obasi di elu (God living in heaven). They also believed in ancestors, in spirits or divinities with their various names and derivative functions, he added. [1]

Mbiti further pointed out that in West African traditional belief, deities' divinities or spirits were categorized into formal and human forms. [2] Ugwu agreed with this view, pointing out that the nature spirits are forces, while the human spirits are those ones that can be identified with the living like 'chi', or the departed ones (ancestors). He said that West Africa has a rich cultural heritage and that every West African country has a myriad of deities. [3]

The essence of these myriad of deities is to see that the society functions harmoniously as one. This sense of oneness of community and harmonious living, which is highly cherished and valued in Igbo land and Africa in general, is most significant in Ikwuano. And one of the highest instruments of maintenance of this orderliness is the "Ekpe" cult commonly called and known as "Okonko" cult.

1. This paper is trying to present historically the ancient cults that preserved peace, unity, obedience and humanity in the lives of our forebears. In the sense that with fear and trembling, the people of old obeyed the laws of Okonko, even when it was not comfortable to them 
2. With sound moral obligation, our forebears followed their religious obligations without complaint. If Christians of Twenty First Century can serve God with the same level of moral integrity, our earth will be a desirable place on inhabitation.

3. The methodology adopted in this work is historical, as everything including oral interviews was based on history.

\section{Historical Background of Ikwuano}

The people called Ikwuano are occupying a vast area of land at the end of South-Eastern part of Igbo land of Nigeria. Osondu explains that Ikwuano is located at approximately. $5^{\circ}-25^{\prime} 60$ degrees north of the equator and about $7^{0} 34^{\prime} 0^{\prime}$ ' degrees east of the Greenwich Meridian. The Northern border of Ikwuano is three (3) miles $(4.8 \mathrm{~km})$ South of Umuahia urban centre, the capital of Abia State of Nigeria. The Southern border is 15 miles $(24 \mathrm{~km})$ from Ikot-Ekpene, Akwa Ibom State. Ikwuano is bordered by Olokoro and Ibeku communities in the North and North West, and by Bende in the East; Nkalu in the South-East. Obot-Akara in the South and Ohuhu Nsulu, Amachi and Nenu in the South and South-West [4]

The name 'Ikwuano' etymologically indicates that there are four different ancient kingdoms that make up the community called lkwuano. These include Oboro, Oloko, Ariam... and their ancient kingdoms. The area before 1991 was called Ikwuano / Umuahia. But in August 1991, it was given full-fledged local government autonomy. It is made up of 46 autonomous communities with a land mass of about 268.71 square kilometres, an extensively rich farming land and agricultural potentials. Ikwuano is blessed with arable and table land. Their major occupation is agriculture. Villages had neither kings nor rulers; they rather had leaders who in most cases were the eldest male members of their communities.

Okwara, Oluigbo and Arinze observed that the elders had no executive powers. Man of substance, especially the wealthy and titled ones, occupied prominent positions and could influence community decisions on' important issues. Within these societies, various secret and title-taking societies existed and members of these societies enjoyed respectable standing in the community. Courts and prisons were generally absent. Citizens' activities were guided by customs, conventions, taboos and sanctions. Disputes were resolved in adhoc assemblies and if anyone of the parties disagreed with the decisions given, the oracle was consulted. [5]

This was the environment into which 'Okonko' was born and this gave her excessive influence over the social, economic and religious life of the people. The society as constituted was porous in terms of administration, organization and governance and the rich and title holders exploited the opportunity. On arrival of Okonko, the people now saw it as a better umbrella.

\section{3. 'Okonko' Cult as a Cultural Practice}

'Ekpe' or 'Okonko' as it is called in Ikwuano is not a deity, but a cult which has gained prominence and influence over the people's socio-cultural, political and religious lives. From oral tradition, 'Ekpe' society came into Ikwuano through their neighbouring community, the Akwa-Ibom State, (according to Elezu). That is why in Ikwuano, the president of the society or cult is called 'Akan' or 'Nna Ekpe". 'Akan' is an Ibibio language and non-members are not allowed to know the meaning of Akan, hence this is dreaded and no one cared to ask why. Even the members cannot explain its meaning hence it is one of the secrets of the cult. The Akan who is believed to be possessed by the spirit of the ancestors does not come out in the day to avoid being seen by "Okpo" a non-initiate or common man. [6]

The history behind the importation of this cult into Ikwuano, according to Richard Mgbugbo, was that "in the very early days, our people and our neighbours, the Ibibio people, were fighting and killing themselves, yet we were still intermarrying with them. One day, one of our sons whose mother came from Obiakpo in Akwa-Ibom visited his mother's kinsmen, without knowing that a war had broken out between us and his mother's kinsmen. Obiakpo people had lost many people in that war. On the warrior's arrival at home, it was a day when the 'Okonko' people in their place were meeting. The Ikwuano boy came out and was recognized by one of the warriors and they wanted to seize him, his uncle in whom he visited saw that he could not stop them so he made the boy to run into the "Obi Okonko' and crossed the "Omu". (Fresh palm frond) By so doing, he became a member and they could no longer kill him while the rite of initiation was done for him by his uncle. When he completed the processes, he returned to his village and narrated the story and his people said, if that will end our constant war with them which our inter-marriages have not been able to stop, let us go and initiate ourselves. From that time, the constant boundary/inter-tribal wars seized until the Nigerian civil war that opened a new wound across that boundary.

\section{Initiation}

The first stage in the initiation is called 'Itu Nkpara'. This is a process of registering a small child, son or male children of a wealthy man who desires to initiate his children at a tender age. They could take part in any ceremony and meetings, except that they were not introduced to the secrets-as children, so that they will not reveal them. Stage two is called 'Ikpu Omu'. To an adult, this is the first stage. The person crosses the place decorated with the fresh palm frond and sits with other 
members. They can administer questions, punishment and anything they fill can be used to test the person to see if he will resist any pressure that may force him to reveal the secrets of the cult. After this stage, comes the third called 'Njiji Ekpe, or Ekpe Ukwu. At this stage the young member begins to learn the tradition, norms and customs of the land and of the cult, as to prepare him for the honourable position of leadership in the land. Another stage is the "OKIRI. ALA". At this point, all the secrets are revealed to the new member, including the signs and symbols made on the ground. He has to strictly memorize them, so that when he goes to another village, it will remain a sign of his strong membership of the cult. The attainment of the status of Okiri ala is the highest position anyone can reach. "The 'Nna Ekpe or Akan' as the president of the cult is called, like every other African setups especially in Igbo culture, when he is coming out, the members will shout as to make a heavy noise such as 'Okpoo gba-a owh'! After shouting it severally, if they meet anyone and think that he/she has seen the mask, the person will be beaten to stupor, yet he/she will give them one big goat, seven tubers of yam, fourteen gallons or seven jars of palm wine, one bottle of hot drink and certain amount of money. To avoid such heavy penalty, whenever they shout, everybody will be on the run and widows will even put off lights in their houses or the member will destroy widows that are open. All these threats are meant to boost Ekpe members ego and instill unnecessary fear on non- members. Because 'Okonko' is a cult from the riverine areas or community, the last point of initiation is called 'ida-iyi', (bathing in the river or stream). In that case, the initiate is lead to the stream in the tick darkness of the early morning hours about 3 to $4 \mathrm{am}$, or at the "first cock crow". When they come back from the stream at dawn, they will escort him to his house where hot drinks will be used to celebrate the consummation of the process of initiation. The person then becomes a full-fledged member of Okonko, knowing all the secrets and is able to guide others and also stay where elders are talking and where law makers are gathered.

'Okonko' is a cult of the wealthy and ruling class. They pay heavily and the money raised, goes into two things mainly: (1) Entertainment as they always entertain themselves lavishly, and (2) building thatched houses for widows, as well as to decorate their meeting places and village square during village or community functions

\section{Functions of Okonko Cult in Relation to Security of Human Life and Property}

'Okonko' is a cult and not a God. It does not have a set out period for any celebration in Ikwuano. As all the titled men, wealthy men and elders are members; they can stay in their meeting places to take decisions concerning the progress of the village both socially, religiously and morally. In this vein, Onyejekwu is of the opinion that Okonko was a powerful institution, which dominated the government of the community. During the pre-colonial and colonial era, Okonko promulgated laws, enforced laws and had different techniques to its rules and regulations that performed the function of social control. [7]

This means that Okonko cult played the role of preventing crime and checking corruption in the society.

\section{Settlement of Land Disputes to Prevent the People from Killing Each Other}

If there was land dispute, which could lead to killing of people, Okonko members normally would be invited to settle the dispute by barricading the place with fresh palm fronds, $O m u$ '. Nobody could enter into the land until they were given the verdict. Anyone, who ignored their verdict, would be forced to pay heavily, and because of the heavy penalty, nobody dared to disobey them. Therefore, among the religious and social functions of Okonko is the settlement of crucial disputes in various Igbo communities. And because "omu' is regarded as a religious object, nobody dared to touch it when it was kept in such conditions.

\section{Insecurity of Life such as Threat of War}

Ugwu said insecurity of life and property within the society have not only been the bane of sustainable development, but has caused a lot of crises, wickedness, looting, death and man's inhumanity to man. To avert the danger caused by insecurity, man has constantly been searching for freedom, protection; to ensure longevity, it is not surprising therefore that Pearlstein (1999) suggested and developed possible strategies for peaceful co-existence and security of human lives and property. [8]

In ensuring that there is peaceful co-existence among the neighbouring communities, 'Okonko' was seen as a bridge between two neighbours in the tie of oneness of 'Udu-Ekpe,' or the 'Okonko' drinking pot. Anybody who drinks from this pot is not expected to pay/do evil against a member as well as plan war against a community where they know their fellow 'Okonko' men.

On the impact of culture on the security of human lives and property, Ugwu says that masking tradition has been an integral part of African traditional religion and culture. In African societies, there are various types of masquerades. In Igboland alone, there are innumerable numbers of masquerades. Among Northern Igbo area comprising Nsukka and Udi group of villages are identified with 'Odo', 'Omabe' and 'Akatakpa' and other social masking traditions. [9]

Though konko' is not like 'Odo' and 'Omabe', they do play similar role in the protection of people's lives and property. While 'Odo' and other masquerades start from 
their religious point of view, 'Okonko' starts from social stand point and spreads her influence through politics, via governance. Again, while 'Okonko' is not purely a religious group, it is clear that an Igbo man does not and cannot do anything completely outside his religion. So, God is in everything including the social life which implies that when an 'Okonko' person goes outside the rule of standing on the truth always, the gods do not wait for another special invitation to attack him.

Nwosu extends the argument by noting that before any major feast or initiation ceremony in Igbo land, the 'Eze Okonko' "which Ikwuano people call Akan or 'Nna Okonko" makes sacrifices to the mother spirit, inviting her to grace the occasion with her presence; Her presence is believed to be inevitable if the ceremony or initiation is to be successful. The 'Okonko' society also performs rituals on behalf of the community. The community passes through things such as cleansing process in order for all the evil things and sins of the community to be forgiven. [10]

"Okonko" in Igbo land is a significant cult group that played and is still playing important roles in the lives of the people, it cannot be ignored even by Christians, seeing that its religious role is significant and realistic, They are known to dispense justice to both big and small, low and high without partiality. One can bribe or buy magistrates or lawyers over, but no one can buy an 'Okonko' man over. It not only 'Okonko' in Ikwuano that plays this type of role as the Oba or Ezeji people have quite a lot of similarities with the Ekpe/Okonko' people. They believe so much in fair play and law of retribution, that is, if you take bribe or show favour even if it is your wife, child / children, brother, sister, relative, friend of any kind, you should be ready to die before then next twenty four (24) hours

'Oba,' is a cult of the rich, they believe in flamboyance and luxury. Before you can be admitted, you must have harvested at least 24 bans with at least 24-30 stakes of yam in each ban. So that : (1) Umuada can take one ban, Umunna can take two bans not stakes, the poor can also take 2 or more depending on the size of the village, then the older Oba people can take 4 or 5 bans and yet the person will still stand. Their god is Ahiajoku or Ifejoku as some do call it, but like the Okonko, they used large earthen water pot to mix all their wine and drink together which made for prefect communion, oath and covenant taking. They also owe allegiance to the goddess of the earth as the god that makes the yarn to produce fat tubers. Oba people do not give someone wine, rather one dips his own cup and takes it with his own hands from the Udu Oba. After drinking from there and if anyone dared to tell lies, he would die because that pot is like a god itself and that which they have seen and known rules their sense of action and judgment".

In this vein, Nwosu explains that of all the societies in Igbo land, 'Okonko' has the central-place of importance in the lives and affairs of every free born male adult in the land. "Okonko covered the traditional religious and social lives of the Igbo prior to the advent of Western culture and
Christianity. The society is primarily a social, political, religious and judicial organization, established for the purpose of maintaining justice, peace and order in Igbo land. This means that 'Okonko' society prevented crime in the community. It was a vital society that reassured the rest of the populace concerning the enforcement of customary laws, especially' in land matters and marriage cases. [11]

Okonko and Oba are the nearest police post and appeal court for an average Ikwuano man and woman. That does not mean that elders and kinsmen do not preside over cases but in the case of urgency of such as dispute 'Okonko and Oba people are preferred in the sense that the gods who are in control of the 'Udu Oba' and ancestors who are physical in the midst of the Ekpe/Okonko' cannot allow them to dispense injustice. Death penalty awaits any 'Ekpe' person/member that dispenses injustice. They are under obligation to tell nothing but the truth and that is why an Okonko or Oba man speaking anywhere in the world will be proud for two reasons: that he is recognized all over (his known) world as a man who cannot and will never tell lies. They are tested and trusted in that. Also, he is recognized as one who is able to stand the test of time in terms of wealth. This is one of the criteria to qualify for the conferment of the title and initiation into these cults. They also see themselves as first class citizens. Women under siege seek refuge in an 'Okonko' man's house. If there is a problem between a man and his wife, the woman is free to run to the house of Okonko or Oba man for protection as they are so trusted. They dare not touch her in terms of sexual misconduct. It is a common proverbs that "Nkita adigh ata okpukpu akwunyere ya n'olu 'a dog does not eat the bone that is huge on its neck' as it is assumed that everybody within the kindred or family isunder his control. Therefore, he cannot do such an abomination; to help him overcome such is one of the reasons why he should have many wives.

\section{Means of Securing People's Lives and Property}

\subsection{The Use of Taboos in Securing Human Life and Property}

Okonkwo was simply acculturated into what had been, it had to make use of the already existing cultural norms, rules and laws governing the people which the use of taboos was one of them.

Ugwu says;

In African traditional societies various taboos exist. It is a taboo to kill or mairu totemic animals and trees; more so, it is a taboo for one to commit adultery or to break the virginity of young girls before puberty, or to have sexual intercourse with a woman that is under menstruation. There are other countless taboos related to ancestors, divinities, priests, farm work etc. Truly, the purpose of 
such restrictions is primarily to protect or sustain acceptable and good moral behaviour and ensure security of human life. [12]

Taboos are moral laws, restrictions; prohibitions meant to forbid people specifically from doing certain things that can lead to a kind of chaos, quarrel or defiling the land, or annoying the ancestors or gods. When a taboo is committed, there is always a doom pronounced by the god through the ancestors or soothsayers. Taboos are always enforced by all and when a taboo is breached, the punishment always affects innocent souls in the kindred, or other members of the offender's family. So to be on the safety, everybody joins hands to checkmate such things like stealing, adultery, excessive anger, sexual abuse on girls and ladies, and anything the community deems necessary.

\subsection{Leakage of Secrets}

The village may take an important decision affecting its members and other villages. Secrets must be kept. Anyone who leaks information, even if it's one's daughter, sister or other relatives are married there, or that is where you married or where your mother came from, if it is a matter pertaining to war or life, the defaulter may be killed or heavily penalized.

All these are possible because the chief of Okonko or 'Nna Okonko' who is to them regarded as an ancestor cannot be provoked. If anyone dares to try it, he/she would pay with his/her own life as the ancestors cannot tolerate humiliation or disappointment from anybody. So, to escape from the wrath of ancestors, the best is to obey whatever one is asked to do, hence disobedience to the leaders of the society means disobedience to both the ancestors and deities. This is what Awolalu meant when he says that in African communities, there are sanctions recognized as the approved standards of social and religious conduct on the part of individuals in the society and of the community as a whole. A breach of, or failure to adhere to the sanctions is sin, and they incur the displeasure of the deity and his functionaries. Sin is, therefore, doing that which is contrary to the will and directions of deity. It includes any immoral behaviour, ritual mistakes, any offence against God or man, breach of covenant, breaking of taboos and doing anything regarded as abominable and polluting. Awolalu and Dopamu. [13]

It is the members of 'Okonko', elders and other titled men that represent the rest of the members of the community before God, and the ancestors. They hear, interprete as well as answer back to the gods. Any disobedience or act of contempt on their word is regarded as having been done directly to the gods and ancestors.

In terms of the negative impact of 'Okonko', it should be noted as follows:

1. They use intimidation and force to rule. If a person disobeyed them, they would send their younger members who are sons of the wealthy men who were initiated at their most tender ages, to beat hell out of the person and while dealing with the person, if the person dies, nobody would ask because all the powers are in their hands.

2. They put the initiation cost very high in order to scare the poorer ones and so monopolize the judicial authority of the community within themselves.

3. They just brand their activities secret in order to instill fear in people's lives as to maintain their position as the ruling party, so they intimidate everybody. But because of their sincerity and concern for the poor in judgment and peacemaking, like Joe, in his book (The dead are not gone) I can say that 'Okonko' is the forerunner of Christ in Ikwuano and other parts of Igboland where they exist.

From the foregoing, it presupposes that masquerades act as checks or guards to possible immoral behaviours that can lead to insecurity of lives and property. "Africans frown at promiscuity, unwanted pregnancy, abortion, infighting, bickering and dickering, heart breaks and casting of spells on others. Women who are wayward and drink alcohol (palm wine and other locally brewed alcoholic drinks) that ridicule the community are also controlled by the use of these masquerades.

\section{Influence of Modernity on 'Okonko' Cult Group in Ikwuano}

The Western civilization and modernization influenced every sector of life in Africa. The 'Okonko' people were not exempted, they were also affected. Speaking on the effect of civilization or urbanization on African culture, Okwara, Oluigbo and Arinze in their joint publication stated that urbanization is also a process of social change involving an increase in the proportion of total population concentrated in towns and cities relative to the proportion in the rural area. This social transformation, they said, involves, along with shifts in patterns of population settlement, shifts in the locus of power and influence from the rural to the urban area. Huntington underscored this when he argued that as the growth of the city becomes an index of measuring modernization, the city becomes the new locus of economic activities, new social class, new culture and education. [14]

Because of the urban population density, it is not too easy for people, even those who live in one house to know each other especially with the 'flat-building' system. Again, the people in the cities came from different places with different life-styles and behavioural attitudes, therefore, the possibility of monitoring, supervising and dictating for anybody on what to do, how to do it, where to go, foods to eat, wives to marry, titles to take, type of work to do etc becomes impossible.

In the cities, every man takes to his own way of life and 
the type of religion to join for these reasons:

1. Because the traditional gods are no longer worshipped well with all the rituals observed. Their efficacy seemed not to be felt and people look down on the rights, privileges and duties of both the gods and their agents. Since the white man introduced the law court, the authorities of 'Okonko' people have been undermined and their influence is fading.

2. Since the influence of the gods are no longer felt as strongly as before, some of 'Okonko' people are defaulting in their sincerity, so people now prefer law courts to them.

3. The use of other law enforcement agents to enforce compliance to community laws has also reduced their power and influence.

4. Because the power and influence of the ancestral spirits have lessened, and it seems that the power of the "Udu-Oba", the communion drinking deity which was in charge of sincerity, is no longer effective. Some of them now pervert justice, favouritism has set in and this is affecting the influence, powers and is also challenging the authority of Okonko. Those now who have gone to the cities, live on their own, control their own affairs, coming home to join in the village ritual and culture seems unrealistic and unreasonable

5. Because of western education, people who are educated now see certain decisions as being above 'Okonko's jurisdiction. Therefore, their potency and appropriateness to certain issues are being questioned.

These and many others are the ways through which modernism have adversely affected 'Okonko

\section{Recommendations}

I do here suggest that:

(1) Okonko should not be allowed to phase out or fizzle away; it should be sustained as its usefulness has been very relevant in preserving societal norms.

(2) The state and other traditional rulers should encourage their existence.

(3) The church should not see those who practice Okonko as heathens because they do not have any deity they are venerating/worshipping

(4) The few who are still living should be allowed to operate but should be encouraged to live a fully dedicated life as before, to restore the past glory and dignity of the cult.

(5) The church should not discriminate against their members if they still attend their cult meetings.

(6) The 'Okonko' group should stop intimidating those who are not their members by beating and surcharging them for nothing,

(7) 'Akan' is just a mere mask, meant to bring honour and respect to the cult to make people take their instruction. They should stop terrorizing people especially Christians with it. These and others will make for better harmonious and peaceful coexistence, which everybody should join hands to seek for.

\section{Summary and Conclusions}

We have seen that Christianity came into a community that already had its concept of nature, life, culture, custom religion and all other social and religious life styles well developed.

The idea of organizing the welfare of the community depended on organs like the 'Okonko'

The 'Okonko in Ikwuano was imported from their neighbours, the Akwa Ibom people.

Its initiation had four stages. The "itu-nkpara" can be likened to the infant baptism of the Christian church, the"Ikpu-omu", the "Okiriala" and the "Ida-iyi" which is the final stage.

The 'Okonko', though an imported culture, became the ruling party which was later absorbed and monopolized all the powers through the membership of the wealthy, outspoken, and titled men in the community who then used the opportunity of their normal meetings to influence every other's event in the community, and they were seen as ruling the people with intimidation.

But in all that, their rulership, on the other hand, was seen as fair, hence fair play and justice was exhibited to a large extent due to the power of the gods. They, indeed, did the work of protecting the lives and properties of the people.

King Solomon of the bible recognized that 'money is a defence'. Again, he said "A feast is made for laughter, and wine maketh merry. But money answereth all things" Ecclesiastes 7:12 and 10:19 respectively. This means that in the Jewish traditional religion, such things like the wealthy monopolizing the seat of authority is still obtainable. So in the South Eastern Igbo land of lkwuano, the 'Okonko' cult exercises absolute influence, authority and rulership.

Despite the fact that they were so feared and respected, they ruled with utmost fear of the gods who also exercised a higher supreme influential power and authority over them. Because of the significant position they occupied, every other person seemed to be responsible to them while they were responsible to God and the ancestors. Because of all these checks and balances, everything seemed to be moving on well, hence nobody was free to do whatever he or she wished to outside the will of both the community and the gods.

\section{Internet Sources}

Osondu O. 2012 the History of Ikwuano itittp.wwwik wuanonationaluscanda 


\section{REFERENCES}

[1] Agha, A. U. (1996) Christianity and Culture. Enugu; Teemac Global Communications.

[2] Arinze, F. A. (1970) Sacrifice in Religion. Ibadan; University Press.

[3] Awolalu, J. O. and Dopsmu P. A. (2005) West African Traditional Religion. Lagos; Macmillan Nigeria Publishers.

[4] Ezechi, J. C. (2011) The Dead Never Gone. Enugu; Kingsley's Publishers.

[5] Mbiti, J. S. (1970) Concepts of God in Africa. London; As in Ugwu 2007.

[6] Mbiti, J. S (1975) Introduction to African Traditional Religion. London; Heinemann Publishers.

[7] Morris, G. W. and Lois I. W. \& Co. (Ed.) (1992) the Complete Christian Dictionary. California U.S.A.; International Bible Society Publishers.

[8] Okafor, B. N. (2001) Philosophy of Religion. Obasi; Olu Book Land Bible Publishers.

[9] Okwara, P. Oluigbo C. and Arinze M. O. (2009) Nigerian Peoples and Culture. Onitsha Nigeria; Umark Printing and Publication.

[10] Sally, W. (Ed.) 2000 Oxford Advanced Learners Dictionary, New York, Oxford University Press (maker).

[11] Sally, W. (2000) Oxford Advanced Learner's Dictionary of Current English (Sixth Edition) Oxford University Press.

[12] Uchendu, V. C. (1965) The Igbo of South-Easthern Nigeria. New York: Holt, Rinchart and Winston.

[13] Ugwu, C.O. (2002) Man and His Religion in a Contemporary Society. Nsukka: Tobus International Press.

[14] Ugwu, C.O. 2002 Man and His Religion in a Contemporary Society Nsukka, Jobus International Press. As in Journal of Religion and Human Relation 2007. In Ugwueya L. E. (Ed) (2007) Journal of Religion and Human Relations 